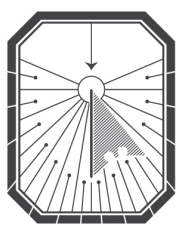

KYIV-MOHYLA

LAW \& POLITICS JOURNAL

KYIV-MOHYLA SCHOLARLY PEER-REVIEWED JOURNALS

Responding to Hybridity in an Unstable Neighborhood: The Efficiency of the EU State-centric Approach to the Crisis in Libya and Ukraine

Author(s): Luca Raineri, Kateryna Ivashchenko-Stadnik, Roman Petrov

Source: Kyiv-Mohyla Law and Politics Journal 6 (2020): 1-25

Published by: National University of Kyiv-Mohyla Academy

http://kmlpj.ukma.edu.ua/ 


\title{
Responding to Hybridity in an Unstable Neighborhood: The Efficiency of the EU State-centric Approach to the Crisis in Libya and Ukraine
}

\author{
Luca Raineri
}

Researcher

Sant'Anna School of Advanced Studies, Italy

\section{Kateryna Ivashchenko-Stadnik}

Senior Research Fellow

National Academy of Sciences, Ukraine

\author{
Roman Petrov \\ Jean Monnet Chair in EU Law \\ National University of Kyiv-Mohyla Academy, Ukraine
}

\begin{abstract}
This article investigates the complex problems arising from the discrepancy of traditional liberal crisis response approaches in the new type of complex emergencies. Based on the in-depth empirical analysis, it examines the EU role in addressing security sector reforms, humanitarian assistance and warfare in Libya and Ukraine, two key EU neighboring countries with ongoing military conflicts. It is argued that the observed over-emphasis on state-centric stabilization measures, with its main focus on formal state structures, fails to deal with the hybrid dynamics of conflict and peacebuilding in both countries. It is suggested that to shape comprehensive crisis response in an unstable neighborhood a multi-layered perspectives approach to security, sensitive to plural agencies and informal rules, should be developed both outside and within EU borders.
\end{abstract}

Key Words: European Union; crisis response; hybridity; security sector reform; humanitarian assistance; stabilization.

\section{(7)}

\section{Introduction}

The crisis response policies of the European Union (EU) are undergoing a significant shift. The original ambitions of the EU - rooted in a normative commitment to liberal conflict transformation and democratic peace - are giving way to an alternative approach focused on conflict management, stabilization and containment. ${ }^{1}$ This

$1 \quad$ Oliver Richmond, Sandra Pogodda and Roger MacGinty, "Good intentions, mixed results A conflict sensitive unpacking of the EU comprehensive approach to conflict and crisis mechanisms." EUNPACK Working Paper D.3.2. (2016), 2. Karolina Pomorska, Gergana 
transition appears to corroborate studies that anticipated the limits of the EU's emphasis on soft-power and liberal universalism. ${ }^{2}$

This evolution is most evident in EU policies vis-à-vis the neighborhood area, reframed from "a ring of friends" 3 to "a ring of fire" in response to compelling security imperatives and a particularly volatile strategic environment following the Arab springs and renewed Russian assertiveness. In recent years, therefore, the EU has traded its normative commitment to long-term liberal reforms for a greater emphasis on shortterm crisis response and stabilization. As part of the November 2015 review process, the new European neighborhood policy (ENP) explicitly took "stabilization as its main political priority" while in 2016 the new European Global Security Strategy (EUGS) confirmed this approach, arguing that stabilization leads to resilience. EUGS thereby subsumed the ENP's shift within an overarching framework that tempers ambitious normative goals with a sobering call to "principled" pragmatism.

With the Union's prioritization of stability ultimately trumping its oft-repeated commitment to liberal norms, scholars argue that EU ambitions to build a security community in the neighborhood have faltered. ${ }^{4}$ However, it would be far-fetched to conclude that this emphasis on stabilization is tantamount to a wholesale abdication of its liberal posture. After all, as long as negotiated settlement and peace-agreements remain central to crisis response, stabilization can be seen as one tactical option on the broader menu of liberal peacebuilding. ${ }^{5}$ Brussels's insistence that crises in Ukraine, Syria and Libya cannot be solved militarily suggests that the EU has not relinquished this approach. And yet its increasing use of targeted sanctions against "peace spoilers" demonstrates growing eagerness to combine carrots with sticks in incentivizing compliance and deterring free riding. The EU, therefore, still appears normatively committed to liberal type, procedurally satisfying political settlements while its dwindling emphasis on democracy and human rights also suggests a less prescriptive stance on the outcome of these processes.

In spite of the relevance of these transformations, we still lack fine-grained evidence about how this strategic shift in crisis response translates into concrete policies and the extent to which these actually differ from previous, "more liberal" templates. Addressing the puzzling, oft-noticed gap between EU foreign policy ambitions and

Noutcheva, "Europe as a Regional Actor: Waning Influence in an Unstable and Authoritarian Neighbourhood." Journal of Common Market Studies 55, no. 1 (2017): 165-76.

2
Ian Manners, “Normative Power Europe: A Contradiction in Terms?" Journal of Common Market Studies 40, no. 2 (2002): 235-258.James Goldgeier, Michael McFaul, "The liberal core and the realist periphery in Europe." Perspectives on European Politics and Society 2, no. 1 (2001):1-26.

Romano Prodi, "A Wider Europe: A Proximity Policy as the Key to Stability," in $6^{\text {th }}$ ECSA World Conference Peace, Security and Stability International Dialogue and the Role of the EU.

(Brussels: on 5-6 December 2002).

4 Pernille Rieker, External governance as security community building: the limits and potential of the European Neighbourhood Policy. (London, UK: Palgrave Macmillan, 2016) 224.

Mary Kaldor, Global Security Cultures (Cambridge, UK: Polity Press, 2018) 115-16. 
results, discourses and practices, this article asks: how are EU stabilization responses to crises in the neighborhood implemented, in practice? To what extent is the emphasis on stabilization modifying, undermining or complementing EU liberal ambitions vis$\grave{a}$-vis its neighborhood? To answer these questions, the article explores the idea that stabilization-oriented EU crisis response does not radically break with the idealistic thrust of liberal peacebuilding; instead, it pragmatically cherry-picks certain tools and measures from the liberal peacebuilding menu over others. In particular, we argue that this stabilization focus underpins a specific emphasis on what might be called state-centric crisis response, manifesting the EU's declining willingness, or capacity, to deal adequately with actors and logics that operate informally and are only partly integrated into the state. The article provides evidence that such developments are premised on an inadequate and reductionist ontology; and, in turn, the failure of the EU's state-centric approach to deal with the realm of informality and hybridity can help explain the unconvincing performances of EU responses to crises erupting in the neighborhood: Libya rates as "the most worsened country" in the world for the past decade in the Fragile States Index for stability; ${ }^{6}$ and Ukraine, since the outbreak of the Russian aggression in 2014, was "the most worsened country for 2015 " and since then remains among the "warning countries" with little progress made.7 To this end, the first section of the article clarifies the concepts of state-centricity and hybridity, and introduces an analytical framework to detect their empirical manifestations. The subsequent sections focus on the quintessential cases of Libya and Ukraine and provide qualitative data to examine how EU crisis responses are carried out in the key domains of security sector reform, humanitarian assistance, ${ }^{8}$ and hybrid warfare.

\section{Framing the State-centric Approach to Stabilization}

Although peace studies literature has interpreted liberal peacebuilding in divergent ways, both liberal thinkers and their critics agree that the liberal peace framework is "state-centric," 9 geared towards building formal state institutions (or, critical scholars argue, imposing them from above). More specifically, the normative peace standard intervened-upon states are expected to align with consists of a Weberian state ideal-

$6 \quad$ Patricia Taft, "Libya Continues Path as the Decade's Most Worsened Country." Fragile States

Index, The Fund for Peace (2020): 27, 28. Acessed December 13, 2020, https://fragilestatesindex. org/2020/05/10/libya-continues-path-as-the-decades-most-worsened-country.

7

J. J. Messner (ed.). Fragile States Index, The Fund for Peace (2020): 6. Accessed December 13, 2020, https://fragilestatesindex.org/wp-content/uploads/2020/05/fsi2O2O-report.pdf.

8 For evidence-based overviews of the EU responses to SSR and humanitarian assistance in other countries (including, beside Ukraine and Libya, Afghanistan, Iraq, Mali, Serbia and Kosovo) and unpacking the EU's integrated approach to external conflicts and crises see publications of the Horizon-funded EUNPACK project http://www.eunpack.eu/publications.

9 David Roberts, Liberal peacebuilding and global governance: beyond the metropolis. (London: Routledge, 2011), 205-06. 
type, defined as impersonal bureaucratic rule exercising a practical monopoly over the means of violence. ${ }^{10}$

For liberal orthodoxy, building Weberian-like states represents only one - albeit central - measure in a broader transformative package for promoting liberal norms, including human rights, good governance, and democracy. By contrast, the priority of EU stabilization crisis response is to strengthen centralized states, focusing more on sovereign prerogatives such as state security and border control and less on internal normative standards. Indeed, the EU's perceived need to allay potential threats has made it less reluctant to cooperate with unaccountable strongmen and authoritarian regimes in both neighborhood and enlargement areas."1

Diminishing EU assertiveness vis-à-vis neighboring partner governments with questionable human rights standards, including for instance Morocco, Egypt, Turkey, or Serbia, provides ample illustration of this compromising attitude. Marking a clear shift from liberal doctrines like $\mathrm{R} 2 \mathrm{P}$ (responsibility to protect), the 'state' targeted by stabilization interventions is no longer seen as threatening but threatened. It is, in other words, increasingly framed as a referent object that needs to be secured against stressors such as terrorism and irregular migration, rather than as a potential threat in itself vis-à-vis other referent objects. EU neighborhood crisis responses thus focus on restoring and stabilizing the capacity of existing state authorities to deliver basic goods and perform their sovereign tasks.

This shift from liberal peacebuilding to stabilization also risks reifying the same nation-state forms the EU itself has sought to transcend, exacerbating the Union's reliance on a reductionist ontology focused almost exclusively on formal institutions, central decision-making and legally sanctioned legitimacy. This comes at the expense of a more fine-grained ontology recognizing that formal institutions are embedded within and operate alongside informal ones, without which they would be unable to function. Informal institutions include customs and practices built upon implicit social understandings, networks of interaction, normed behaviors, and expectations of reciprocity, which are neither officially established nor codified, yet their influence on decision-making often trumps rational-choice and collective deliberation explanatory models. ${ }^{12}$

In particular, state bureaucracies pervaded by patronage politics and neopatrimonial networks deviate significantly from the Weberian state ideal-type

Tobias Debiel, Patricia Rinck, "Statebuilding," in: Routledge Handbook of Security Studies, 2nd edition. eds. M. Dunn Cavelty and T. Balzacq. (London: Routledge, 2017), 322-24.

11 Karolina Pomorska, Gergana Noutcheva, "Europe as a Regional Actor: Waning Influence in an Unstable and Authoritarian Neighbourhood." Journal of Common Market Studies 55, no. 1 (2017): 165-76. 
instead fostering what influential scholarship has called hybrid political orders. ${ }^{13}$ These are defined as "places in which diverse and competing institutions and logics of order and behavior coexist, overlap and intertwine: the logic of the "formal" state, the logic of traditional "informal" societal order, the logic of globalization [...] and so on." ${ }^{14}$ Unresolved conflicts and endemic instability reinforce such tendencies, while the entrenchment of wartime structures-personal bonds, informal economies and privatized protection - in post-conflict settings is a key driver of what peace scholars term "hybrid peace." ${ }^{15}$ In particular, Mary Kaldor describes hybrid peace as characterized by "symbiotic relations among military, security-intelligence agents, political elites and organized criminal elements that developed under the cover of war but within thickening webs of relations with official business, diasporas, NGOs, as well as local religious institutions." ${ }^{16}$ Hybrid political orders may well stem from indigenous processes of state formation and transformation, however, rather than external intervention. This has led critical peace scholars to call for greater sensitivity to hybridity, entailing the recognition that cultural norms, customary authorities and informal security providers may well prove to the everyday of post conflict individuals more beneficial than internationally exported ideas and institutions of statehood. ${ }^{17}$

The state-centric approach to stabilization, we argue, has undermined such a pluralistic understanding of political orders. The EU's state-centricity in stabilizing fragile settings is premised on a specific, normative worldview in which the legitimacy of states depends on their capacity to foster effective territorial control and violence reduction. From this perspective, the securitization of the state implies a rigid dichotomy between the Weberian ideal-type of state, on the one hand, and government failure with its corollary of anarchy and disorder, on the other, thereby ruling out the possibility — that the concept of hybridity provided — of understanding political orders in conflict and post-conflict settings in their own right. Even critical scholars concede that liberal peacebuilding possessed the theoretical tools and political determination to engage hybridity, if only by co-opting "local actors" and "traditional authorities" to expand liberal governance. ${ }^{18}$ As Roberto Belloni notes, "traditional actors, norms and institutions $[. .$.$] are empowered to operate within the liberal peace framework$

13 Daniel Bach, Gazibo Mamoudou (eds.). Neopatrimonalism in Africa and Beyond. New York: Routledge, 2012, 164.

14 Peter Albrecht, Moe Lousie Wiuff, "The Simultaneity of Authority in Hybrid Orders." Peacebuilding 3, no. 1 (2015): 1-16.

15 Oliver Richmond, Audra Mitchell, Hybrid Forms of Peace: From Everyday Agency to Post-Liberalism. Basingstoke: Palgrave Macmillan (2012) 78.

16 Mary Kaldor, Global Security Cultures. Cambridge, UK: Polity Press, 2018, 189.

17 Oliver Richmond, Sandra Pogodda and Roger MacGinty, "Good intentions, mixed results A conflict sensitive unpacking of the EU comprehensive approach to conflict and crisis mechanisms." EUNPACK Working Paper D.3.2. (2016), 3.

18 Suthaharan Nadarajah, and David Rampton, "The Limits of Hybridity and the Crisis of Liberal peace." Review of International Studies 41, no. 1 (2015): 49-72. 
and expected to overcome the shortcomings of external intervention through the provision of essential domestic inputs within externally driven goals and priorities." 19 And David Roberts acknowledges that "proper" liberal peacebuilding is bound to recognize the legitimacy of the informal actors and practices that shape people's everyday experiences of peace and conflict. ${ }^{20}$ By contrast, in crisis approaches that prioritize state sovereignty and stabilization, "deviations from the Weberian monopoly on violence $[. .$.$] are rendered invisible and incomprehensible" by design. { }^{21}$

One may therefore explain the unconvincing outcomes of stabilization efforts in the European neighborhood as stemming from this insufficient consideration of informality and hybridity in designing and implementing EU crisis responses.

This interpretation, albeit plausible, requires an adequate empirical substantiation. To this end, we have constructed an analytical framework for detecting instances of a state-centric approach to crisis response, in which a state-centric stabilization approach is defined as a shift towards strengthening centralized states with a clear emphasis on security. In this approach, formal state institutions are treated as both a referent object in need of securing and a tool for projecting such security; from this perspective, more security threats for the EU to address does not coincide with a parallel broadening of the set of security providers to engage with. A state-centric crisis response approach is distinguished by interrelated features: A) channeling material and symbolic resources to and through formal state institutions on the assumption that they follow a purely bureaucratic rationality, thereby emphasizing governments over governance and hierarchical rule over horizontal networks; B) failing to understand informal actors, logics, economies and power dynamics, demonstrated by the lack or neglect of policy tools for accommodating, preventing or engaging hybrid networks of state and non-state actors as either peace partners (in humanitarian relief and post-conflict civil-military cooperation) or peace spoilers (asymmetrical and informal warfare, state-capture, etc.); 3) disregarding the hybridity (unintentionally) triggered or augmented by EU crisis responses, with the resulting tendency to politicize aid provision and blame institutional fragility on external stressors.

To sharpen our research focus we concentrate on Ukraine and Libya. While it is important to acknowledge the significant differences of the conflicts and EU crises responses in Libya and Ukraine, both cases exhibit common structural characteristics which provide fertile grounds for comparative analysis: both are located in the European neighborhood but in the Eastern and Southern subsets respectively, Ukraine and Libya offer the spectrum of variation needed for more nuanced interpretations.

19 Roberto Belloni, "Hybrid Peace Governance: Its Emergence and Significance." Global

Governance 18, no. 1 (2012): 21-38.

20

David Roberts, Liberal peacebuilding and global governance: beyond the metropolis. (London: Routledge, 2011) 145 .

Keith Krause, "Hybrid Violence: Locating the Use of Force in Postconflict Settings." Global Governance: A Review of Multilateralism and International Organizations 18, no. 1 (August 12, 2012): $39-56$. 
Both face major security crises which, erupting in 2014 and ongoing at the time of writing, have met with major EU crisis responses, and the lessons learnt from these crises precipitated the ENP review process and shift towards prioritizing centralized state stabilization. ${ }^{22}$ In both Libya and Ukraine, EU assistance has chiefly focused on the domains of border control and (partial) security sector reform - although with different degrees of priority — including through the resort to CSDP missions. Recent reports suggest, however, that governance in both Ukraine and Libya is significantly influenced by informal networks and actors, thus meeting the definition of hybrid political orders. ${ }^{23}$ These countries therefore provide quintessential cases for exploring the idea that sketchy EU crisis response outcomes reflect the inadequacy of state-centricity in dealing with hybridity.

The empirical analysis focuses on three distinct domains of EU crisis response in both countries, each providing an interesting unit of analysis for observing the hypothesized tensions between state-centric crisis responses and hybrid orders: security sector reform, considered a pivotal domain of hybridization between foreign-sponsored technocratic interventions and local protection dynamics; humanitarian assistance, where liberal peacebuilding frameworks intertwine with enduring conflict networks; and hybrid warfare, where non-state agency and informality allow states to pursue geopolitical goals while ensuring plausible deniability of state responsibilities. ${ }^{24}$

In examining these crisis response targets, an exclusive focus on central decision-making enshrined in policy documents would prevent us from grasping how agency is shaped by wider societal dynamics and security administered in practice through decentralized, informal channels. The epistemological commitment to account for the significance of local agencies, networks of interaction and micropolitical dynamics can instead provide a promising way to explore the constitutive features, and limits of a state-centric approach to crisis response. Accordingly, the evidence herein discussed comes from multi-sited fieldwork comprising approximately one hundred interviews conducted throughout 2017 with mid-level professionals based in Tunis, Rome, Kyiv, Kharkiv, and Brussels, including from the EU, UN, Organisation for Security and Cooperation in Europe, NATO, donor organizations, international and national NGOs and CSOs, local authorities, non-state actors (activists, journalists, researchers) and other local informants. Semi-structured interviews have helped collect and triangulate

22 Kateryna Ivashchenko-Stadnik, Roman Petrov, Luca Raineri, Pernille Rieker, Alessandra Russo, and Francesco Strazzari. "How the EU is facing crises in its neighbourhood: evidence from Libya and Ukraine." EUNPACK Working Paper D6.1. (2017) 4.

23 Abel Polese, "Limits of a Post-Soviet State: How Informality Replaces, Renegotiates, and Reshapes Governance in Contemporary Ukraine." Stuttgart: Ibidem Verlag (2016).MarkShaw, “Enforcing 'Our Law' When the State Breaks Down: The Case of Protection Economies in Libya and Their Political Consequences." Hague Journal on the Rule of Law 7, no. 1 (2015): 99-110. Keith Krause, "Hybrid Violence: Locating the Use of Force in Postconflict Settings," Global Governance: A Review of Multilateralism and International Organizations 18, no. 1 (August 12, 2012): 39-56. 
actors' perceptions of the emerging challenges of EU crisis response. This information has been complemented and contrasted with the findings of an opinion survey on EU crisis response administered to approximately two hundred respondents in the conflict-affected areas of each country.

\section{Security Sector Reform}

The EU has provided aid to both Libya and Ukraine to boost the efficiency and capabilities of their security sectors, measures presented as a way of rendering the countries more stable and resilient in dealing with security crises. In both cases, however, results have fallen short of expectations. ${ }^{25}$ To explain these disappointing outcomes, this section argues that state-centric EU programs in both Libya and Ukraine have failed to adequately apprehend the crucial role of informal networks that permeate the security sector and have vested interests in perpetuating existing hybrid orders.

In Libya, the toppling of the Gaddafi regime in 2011 had left the security sector in huge disarray. The Jamahiriya's security apparatus had essentially been made up of units run by Gaddafi's family members, tribal leaders and foreign mercenaries, loosely institutionalized and de facto reporting directly to the Colonel. ${ }^{26}$ The EU later acknowledged that "during the Gaddafi regime Libya had lacked the blueprint, the infrastructure, the personnel and the legal framework of a 'modern' military." The demise of the Jamahiriya' coercive apparatus was paralleled by the rise of armed groups blending a revolutionary ethos with municipal, tribal or religious loyalties. In this context, the newly appointed Libyan authorities' ability to enforce decisions remained essentially mediated by the precarious consent of non-state militias, who managed to trade their cooperation with the extortion of positional rents. As several reports have documented, extra-legal economies boomed under the cover of militia institutional legitimacy involving the predation of state resources, migrant trafficking, narcotics smuggling, and protection rackets. ${ }^{27}$ Observers noted that "the confusing security scene and the vested smuggling interests make it difficult to discern law enforcement actors from 'rogue' armed groups." ${ }^{28}$ Libya's post-conflict political order was thus hybridized when informal wartime structures, protection economies, and personalized loyalties entrenched themselves within the state bureaucracy.

25 Kateryna Ivashchenko-Stadnik, Roman Petrov, Luca Raineri, Pernille Rieker, Alessandra Russo, and Francesco Strazzari. "How the EU is facing crises in its neighbourhood: evidence from Libya and Ukraine." EUNPACK Working Paper D6.1. (2017) 5 .

26 Peter Cole, Fiona Mangan. "Policing Libya. Form and Function of Policing since the 2011 Revolution." Peacework, no. 117, (Washington: USIP. 2016) 189-9o. Information corroborated by interviews with humanitarian actors and UN officers, Tunis, October 2017. Also see Tim Eaton, "Libya's War Economy: Predation, Profiteering, and State Weakness." Chatham House Research Paper 4 (2018) 2.

28 Valerie Stocker, "Leaving Libya: Rapid Assessment of Municipalities of Departures of Migrants in Libya." Tunis: Altai Consulting 92 (2017) 34-35. 
The growing unbalance between civilian authorities endowed with limited power and legitimacy, and a wide array of self-appointed military leaders maintaining impunity and unconstrained coercion capabilities, eventually precipitated Libya into chaos. Libya progressively attracted large-scale irregular migration flows to Europe, home-grown radicalization, and foreign terrorists. The rapid climb of migration and terrorism to the top of EU security concerns thus urged European leaders to invest in the swift stabilization of Libya. ${ }^{29}$ The EU threw its diplomatic weight behind the negotiations that led to the establishment of a Government of National Accord (GNA) in Tripoli. ${ }^{30}$ The push towards centralization ended up exacerbating existing fragmentations by stirring the resentment of certain regional constituencies, however, while the assumption that the GNA could functionally mimic a Weberian state by monopolizing violence, if only in Tripoli, proved misguided and short-lived. Without a consolidated state security apparatus the GNA was obliged to co-opt informal militias to protect the new government, thus granting their leaders unprecedented leverage to demand positional rents. ${ }^{31}$ Non-state armed actors, some with Islamist leanings and vested criminal interests, were thus able to secure and even strengthen their influence over formal institutions, including ministries, banks, and transport hubs. The failure to adequately anticipate the consequences of the hybrid security governance of Tripoli has contributed to the de facto normalization of a protection racket, boosting the status of militias into cartels of patronage spanning politics, business, finance, and crime. ${ }^{32} \mathrm{In}$ the meantime, the GNA's inevitable involvement in Libya's partisan and venal informal politics has exposed it to increasing criticism and delegitimization, and the inherent instability of Tripoli's "pax mafiosa" triggered new conflicts in August 2018. ${ }^{33}$ In an ironic unintended outcome, therefore, EU stabilization policies against Libyan non-state threats ended up enlisting non-state armed actors as security providers.

The GNA's demonstrated inability to enforce binding decisions despite material and symbolic support from the EU and broader international community prompted a reconfiguration of EU engagement. The mandate of the CSDP EUBAM-mission (EU Integrated Border Management Assistance Mission) in Libya was amended to include providing SSR planning and advice to the GNA. ${ }^{34}$ Subsequent strategic documents emphasized a correlation between SSR assistance, stabilization, border management, and migration control. However, EUBAM's new mandate forced the mission to deal only with GNA representatives, a constraint that not only contradicts

29 Interviews with EU officers, Tunis, October 2017; and Brussels, April 2018.

$30 \quad$ Interviews with EU and UN high-ranking officers, Tunis, October 2017.

31 Peter Cole, Fiona Mangan. "Policing Libya. Form and Function of Policing since the 2011 Revolution." Peacework, no. 117, (Washington: USIP. 2016) 4-7. Interview with UN officer, Tunis, October 2017. Wolfram Lacher, “Tripoli's militia cartel.” SWP Comment 20/2018. (Berlin: Stiftung Wissenschaft und Politik, 2018) 245-46. 
the EU's own comprehensive SSR (State Security Reform) guidelines but also reflects an increasing state-centric approach which has undermined the mission's capacity to understand and deal with Libya's hybrid security sector. ${ }^{35}$

Similarly, the choice of partners to help stem migratory flows across in the country's peripheries, where Tripoli had only a shallow grip, demonstrated a limited EU awareness of the increasing hybridity of Libya's security governance. In the south, EU Trust Funds earmarked for stabilization offered support to centrifugally-oriented tribal leaders and militias only "formally" aligned with the GNA. ${ }^{36}$ In the north, Libyan coastguard training - the cornerstone of the EU response to the migration crisis - was hastily implemented through unscrupulous vetting, ${ }^{37}$ allegedly fostering the intertwining of the Libyan Navy with criminal networks involved in transnational oil and migrant smuggling. While the EU is not the only SSR actor in Libya, its inadequate understanding of the local hybrid political order is de facto helping unpalatable non-state armed actors to appropriate and hijack the reconstruction of the state security apparatus.

Recent findings show that similar dynamics also prevail in Ukraine. After the Euromaidan protests unseated Yanukovych in 2014, the EU initially set out to support the transition by fostering accountability and good governance, particularly in the security sector. Yet the emergence of challenges perceived in Brussels as more compelling, such as terrorism and migration, sucked European resources away from the initial transformative ambitions. In parallel, observers noted growing support for the restoration of Ukraine's sovereign prerogatives, namely in the security sector.

With respect to the task-specific missions, the European Union Border Assistance Mission to Moldova and Ukraine (EUBAM) and EU Advisory Mission (EUAM) have been the two main initiatives directly dealing with the security sector, albeit in different ways and for different periods. ${ }^{38}$ Unlike EUBAM which was an earlier long-established initiative since 2005, EUAM was launched in the aftermath of the crisis in July 2014. EUAM with its relatively narrow advisory mandate of providing technical support to Ukrainian law enforcement and rule of law institutions (the Internal Affairs Ministry, National Anti-Corruption Bureau, National Police, Security Service of Ukraine, Border Guard Service, judiciary, etc.) was a move widely seen as watering down the EU's commitment to Ukraine. ${ }^{39}$ Moreover, this state-centric, top-down approach to sector-specific SSR demonstrated EU measures' inadequate sensitivity to the ongoing

35 Interview with EUBAM officer, Tunis, October 2017.

36 Chiara Loschi, Luca Raineri, Francesco Strazzari, "The implementation of EU risis Response in Libya: Bridging theory and practice." EUNPACK Working Paper D6.2. (2018) 7.

Interviews with EUNAVFOR MED officers, UN officers and Libyan coastguard officers, Tunis and Rome, October and November 2017.

38 Kateryna Ivashchenko-Stadnik, Roman Petrov, Luca Raineri, Pernille Rieker, Alessandra Russo, and Francesco Strazzari. "How the EU is facing crises in its neighbourhood: evidence from Libya and Ukraine." EUNPACK Working Paper D6.1. (2017) 11. 
hybridization of Ukrainian security, thus severely limiting their impact. ${ }^{40}$ Given EUAM's advisory role, the actual implementation of SSR templates depended largely on the cooperation and political will of Ukrainian counterparts. Yet, as seen by EU officials, among the common problems for all EU activities and missions in Ukraine that undermine its efficiency during the crisis was "an identity crisis", as the local partners do not entirely share the goals and agendas of EU missions in Ukraine. ${ }^{41}$ Reframing the emphasis on local ownership through a state-centric lens, the government in Kyiv was identified as the EU missions' main interlocutor.

Yet by taking Ukraine's "Weberian" statehood for granted, the EU's technocratic approach failed to recognize that the security sector in Ukraine does not abide by a purely bureaucratic rationality. On the one hand, Ukraine's security sector suffered from Soviet-era path-dependencies and the long-standing normative, material and symbolic attributes which helped maintain strong Russian influence. ${ }^{42}$ On the other hand, Ukrainian elites have traditionally exploited the security sector as both a source of corruption and a bargaining chip in the political struggle. ${ }^{43}$ These hybrid networks invested in maintaining the status quo obviously put the brakes on reformist enthusiasm.

EU reformers, however, have not relinquished their liberal ambitions of fostering good governance altogether, and fighting corruption has remained a top priority of the Support Group for Ukraine. For instance, EUAM supported the adoption and implementation of the National Defence Law with its focus on defense sector accountability - still one of the opaquest domains of the state budget. ${ }^{44}$ Despite legislative progress, however, post-Euromaidan elites' security-sector budget predation continues, prompting local observers to argue that authorities manipulate and "sabotage real changes." ${ }^{45}$ State-centric diplomatic tools have apparently proven illsuited, therefore, to tackle the informal dynamics underlying Ukrainian politics in Kyiv and beyond. According to several interviewees, local ownership is equated mainly with the government and, as a result, even though there have been some positive examples of regional cooperation with the EU, the template for local needs assessments remained ill-designed. ${ }^{46}$

40 ThierryTardy, "Tackling the challenges of SSR." EUISS Issue Alert 14 (2015)145-46.

41 Interviews with the representative of the Reporting and Evaluation Department at EUBAM Ukraine and the representative of the Public Information Department of EUAM Ukraine, Kyiv, November, December 2017. Shyamika Jayasundara-Smits, "From Revolution to Reform and Back: EU-Security Sector Reform in Ukraine." WOSCAP article D4.14. (2016) 4-5.

43 Interviews with Ukrainian stakeholders, Kyiv, November 2017.

44 Kateryna Ivashchenko-Stadnik, Roman Petrov, Luca Raineri, Pernille Rieker, Alessandra Russo, and Francesco Strazzari. "How the EU is facing crises in its neighbourhood: evidence from Libya and Ukraine."EUNPACK Working Paper D6.1. (2017) 8-10. Interview with Ukrainian political experts and stakeholders, Kyiv, November 2017. Interview with a representative of Donetsk CIMIC and local stakeholders, Kyiv and Kharkiv, October and November 2017. 
Against expectations of a "rational" cooperative attitude from Ukraine's state apparatuses, public procurement (of equipment, weapons, software, etc.) ill practices converge to undermine citizens' allegiance to the state and erode its monopoly on violence and security regulations. This opened up space for non-state or para-state actors to step in as informal providers of community security and protection rackets. With the continuing conflict in the country's east, the widespread availability of weapons has actually increased protection demand and supply alike. ${ }^{47}$ In response, networks associated with sports clubs, nationalist groups and neighborhood associations have formed vigilante militias to protest and, often, to protect commercial interests. Either as a result of their local legitimacy, political collusions, or sheer coercion, many of these groups have managed to penetrate-formally or informally-Ukraine's law enforcement institutions. The use of paramilitary detachments, typically subordinated to the Minister of the Interior (both officially, as with volunteer battalions, and unofficially, with radical groups), is a case in point. As a result, reports indicate that Ukraine's internal security apparatus hosts more and more patronage networks, typically linked to radical groups, which in some cases have engaged in smuggling and extortion or abuses against civilians with complete impunity. ${ }^{48}$

Although the EU aims to tackle security-sector unaccountability and corruption, its state-centric crisis response approach has proved unable to grasp these crucial dynamics and anticipate counterproductive outcomes. The EU's call to involve NGOs as a measure to foster civil society oversight has also proved ineffective, because organizations that are formally non-state but which maintain informal links to state authorities are often privileged, thus reproducing the loyalty-based patronage networks that hinder reforms. When vested interests are involved, as stated in one of the interviews, "obviously, it is not the task" of authorities to "change the system however wrong it is, and they will never invite partners who are going to criticize their activities and raise concerns about the real problems in the sector." 49 Despite the fact that the Ukrainian government remains the EU missions' main direct counterpart, supposedly centralized information about security sector reforms remains hardly accessible, as well as information about EU activities and inputs. Consequently, nearly a third of survey respondents from among the potential recipients of the reforms in Kyiv, Kramatorsk and Odesa remained dissatisfied with the EU's interventions in security sector reform. ${ }^{50}$

This is not unrelated to the EU's reluctance to support local arms-control projects and fight illegal circulation, as theoretically required by art. 12 of the EU-Ukraine Association Agreement. Vyacheslav Likhachev, "Far-right Extremism as a Threat to Ukrainian Democracy." Nations in Transit Brief. (Washington, DC: Freedom House, Freedom House Nations in Transit Brief, 2018) 189-91.

$5^{\circ}$ Perceived overall effectiveness of the EU's interventions in security sector reform based on the survey data, July 2017. 


\section{Humanitarian Assistance}

Since 2014, EU crisis response has targeted both Libya and Ukraine with major humanitarian assistance programs. Illustrating the growing emphasis on stabilisation, much of EU support has been channeled through tools and funds earmarking stability as their main goal, such as the International Organisation for Migration stabilization unit in Ukraine, and the United Nations Development Programme stabilization fund and EU Trust Fund for Africa "for stability and addressing root causes of irregular migration" in Libya. The EU's state-centric approach to stabilization has favored state-driven and state-targeted aid delivery while its lesser attention to civil society has shrunk capacities for independent oversight.

Driven by a sense of urgency in responding to Libya's perceived "migration crisis", European policy makers have sought to prove their efficiency and resolve by expeditiously channeling hundreds of millions of euros of aid to the country since 2015. The speed and scale of this humanitarian response has come at the expense of accuracy, however. With time and access constraints preventing the adoption of needs-assessment and evaluation tools that meet OECD standards, the EU's generous allocations reportedly exceeded both the needs and absorption capacity of local stakeholders. ${ }^{51} \mathrm{~A}$ humanitarian response calibrated more to the anxieties of European constituencies than the actual on-the-ground needs has not only contributed to illconceived project design; ${ }^{52}$ more importantly, it also feeds informal networks grafted onto post-conflict predatory economies. The aid reportedly flooding the humanitarian field without regard for the absorption capacities of local implementers and beneficiaries ${ }^{53}$ has increased potential embezzlement and misappropriation. Given the underpowered Libyan judiciary and limited monitoring and impact assessment of EU projects in Libya, allegations of widespread corruption in the humanitarian sector cannot be substantiated, but perceptions studies suggest that only some of this aid has trickled down to intended recipients: ${ }^{4}$ interestingly, needier beneficiaries in the country's periphery are less aware of and satisfied with EU humanitarian support than better-off stakeholders living close to political centers. ${ }^{55}$ More specifically, subordinating aid to restrictive migration policies demonstrates an inadequate understanding of the economic and social embeddedness of the smuggling economy, arguably another consequence of state-centricity in crisis response. Without taking informal economies seriously, it is difficult to effectively valorise legitimate businesses over the vibrant traffic-based economy enjoying legitimacy at the local level, and tacit support in Tripoli.

$51 \quad$ Interviews with with EU, UN and INGO officers, Tunis, October 2017.

$5^{2}$ Interviews with EU and UN high-ranking humanitarian officers, Tunis, October 2017.

53 Interviews with EU officers, Tunis, October 2017.

54 Interviews with Libyan civil society and international NGOs, Tunis, October and November 2017 . 
EU policies have likewise supported local capacities to manage migratory flows, including in the domain of Search-and-Rescue (SAR) of migrants at sea. Outsourcing such management to formal Libyan authorities without an adequate legal framework, however, has merely boosted the number of migrants in custody. ${ }^{56}$ While EU-funded programs support the humanitarian evacuation of migrants held in official Libyan detention centers - and struggle to keep pace with arrivals - local observers contend that the majority of migrants are actually kept at informal facilities managed by militias. ${ }^{57}$ The EU-sponsored policy of large-scale migrant detention in Libya has thus fueled criminal exploitation and trafficking. ${ }^{58}$ This policy is questionable not only on human-rights grounds but also for its lack of conflict-sensitivity, sustainability, and coherence vis-à-vis the overall goal of stabilization, given that reported collusion between security officers and trafficking networks in Libya has the potential to further empower non-state armed actors. ${ }^{59}$

In Ukraine, too, EU-provided humanitarian support struggles to achieve its expected results. With 35,000 conflict-related casualties, 1.5 million IDPs from the Donbas and Crimea and about 1 million refugees, Ukraine is a priority country for DG ECHO. Since 2014, the EU and Member States have offered over EUR $5^{26}$ million in humanitarian and early recovery aid to Ukraine including food, shelter, health services, education in emergencies, and essential household and livelihood aid, making the EU the largest humanitarian donor and the humanitarian sector one of the best-known and best-rated expressions of EU crisis response in the country. ${ }^{60}$

Politicization and framing biases may have distorted genuine needs-based aid delivery, however, and undermined the impact of such generous funding. Surprisingly enough, the Minsk Agreements address political and humanitarian issues in the same document. In this context, the state-centric opposition equating Weberian sovereignty with stability/predictability and instability with state failure/civil war may have unduly influenced Brussels's estimate of Ukraine's humanitarian requirements. In fact, observers note that ECHO's activity has suffered from Brussels's uncertainties in defining the nature of the crisis in Ukraine. Member states' hesitation in framing the conflict as an aggression rather than a civil war has led to strategies and measures with limited relevance in this specific context. Many EU representatives expecting civil conflict have landed in Ukraine with biased perceptions of differences between people

56 KarsDe Bruijne, FloorEl Kamouni-Janssen, FransjeMolenaar, "European security interests at stake in Libya?."Clingendael Crisis Alert Report. Den Haag (2017) 35-37.

57 Interviews with IOs and NGOs officers, Tunis and Rome, October and November 2017.

$5^{8}$ Information surfaced in interviews with EU, UN, and NGO humanitarian actors, Tunis, October 2017 .

Chiara Loschi, Luca Raineri, Francesco Strazzari, “The implementation of EU crisis Response in Libya: Bridging theory and practice." EUNPACK Working Paper D6.2. (2018) 19-23.

6o Kateryna Ivashchenko-Stadnik, Roman Petrov, Luca Raineri, Pernille Rieker, Alessandra Russo, and Francesco Strazzari. "How the EU is facing crises in its neighbourhood: evidence from Libya and Ukraine." EUNPACK Working Paper D6.1. (2017) 12-15. 
in the east and in other regions ${ }^{61}$ disregarding the fact that ethnic orientation did not lie at the root of the conflict, as recent studies have suggested. ${ }^{2}$ At the same time, Brussels's ambiguous stance of neither explicitly defining the aggression in legal terms nor accepting the de facto annexation leads to an exclusive focus of EU humanitarian action on the Donbas region crisis while overlooking Crimea.

Consequently, the Minsk Agreements do not provide efficient instruments for dealing with disputes over Crimea and resolving conflict in the Donbas, thus nourishing the entrenchment of war-time protection economies and hybrid networks that cut across sovereign delineations, civil-military partitions, and ideological cleavages. In this context, different non-state actors thrive through informal connections with state actors on both sides and humanitarian assistance is hardly exempt from the risk of capture. In particular, given the highly volatile security context, major data collection challenges have hindered the planning and monitoring of funded humanitarian projects and led in some cases to a serious overestimation of needs, thereby increasing the potential for embezzlement, patronage redistribution, and institutional relevance struggles among Ukrainian actors. ${ }^{63}$

The key themes from the fieldwork narratives highlighted that the thorniest issues that require further fine-tuning by the EU of the conflict response in the humanitarian sector require decentralized partnership schemes to be implemented. Special attention should be given to defining the vulnerable (as emergencies develop unevenly across the territories, the definitions based on the existing centrally-drawn templates do not address the needs), ${ }^{64}$ dealing with the violation of international human rights in the NGCA (both Donbas and Crimea) and beyond (something that central authorities tend to underreport when it comes to crimes against journalists and activists but 'usually have to speak up when the information is requested from Strasbourg'), ${ }^{65}$ and implementation consistency (needs assessment cannot be implemented though 'a one stop shop' either in the EU or Kyiv but should be localized in consultations with a wider circle of partners who have practical expertise in the field, specifically, standards of humanitarian aid should be tailored to address the local and seasonal needs, humanitarian projects should be distributed across the country in a more balanced way). ${ }^{66}$ Finally, even though the provided humanitarian assistance is considered to be

$61 \quad$ Interviews with Ukrainian stakeholders, Kyiv, Novermber 2017.

62 Kateryna Ivashchenko-Stadnik, "What's wrong with the Donbas? The challenges of integration before, during, and after the war," in Ukraine in Transformation: from Soviet Republic to

European Society. eds. A. Veira Ramos and T. Lubiva. (London: Palgrave, 2020): 22-6o.

63 Interviews with Ukrainian stakeholders, Kyiv and Kharkiv, October, November and December 2017.

64 Interviews with Ukrainian stakeholders, Kyiv and Kharkiv, October, November and December 2017 .

65 Interview with a Ukrainian media expert, Kyiv, December 2017.

66 Interviews with Ukrainian political experts and stakeholders, Kyiv and Kharkiv, November 2017. As was stated during on of the the interviews, 'it is Kyiv, which speaks on behalf of the regions. 
rather effective ( $44 \%$ of the interviewed beneficiaries were rather satisfied with the EU's humanitarian support which is higher as compared to other forms of the EU's aid in Ukraine), ${ }^{67}$ there is a perceived lack of long-term strategy in the field (notably, with respect to reintegration and resettlement of IDPs, launching rehabilitation centers and introducing demobilization programs for war veterans returning from the east). Here, again, the state-centric orientations in defining the mainstream areas of humanitarian assistance leads to the EU's reluctance to prioritize some of the urgent interventions.

\section{Hybrid Warfare}

In both Ukraine and Libya foreign actors with vested interests in the local conflicts have resorted to unconventional warfare tactics combining irregular operations, covert support to local actors, criminal economies, and aggressive communication. Hybrid modes of warfare largely resort to informality and often rely on hybrid political orders. The tension between the reductionism of the EU's state-centric approach, and the complexity of the hybrid modes of contemporary warfare manifests not so much the inadequacy of what the EU actively does to respond to crises, as for SSR and humanitarian assistance, but what the EU fails to do to prevent conflicts from worsening. ${ }^{68}$

The concept of hybrid warfare has been developed to capture state actors' use of informal stratagems to pursue geopolitical goals. ${ }^{69}$ As war becomes more expensive both politically and economically, middle powers increasingly view informal means as a valuable option for achieving strategic objectives while ensuring some degree of plausible deniability and avoiding international embarrassment. Russia, in particular, has been spearheading this new approach. From a Russian point of view, the development of hybrid warfare capabilities supplied a strategic alternative to resist the belligerency and assertiveness of the West, especially within its own neighborhood. While Russia's initial strategizing in this direction dates to the early 2000 s, the 2014 conflict in Ukraine is widely seen as the first example of its resorting to hybrid warfare in a large-scale, systematic way.

However, the conflict in Libya, too, is arguably part of the genesis of Russia's hybrid warfare capabilities. While European countries were at the forefront of the military

Regions get what was designed for the national level. Local feedback is not taken to Brussels, as the local actors have no authoritative voice to guide the process.'

67 Perceived overall effectiveness of the EU's humanitarian support based on the survey data, July 2017 .

68 To be fair, one should acknowledge that the EU has considerably invested to understand, define and address the challenges related to hybrid warfare, and build up an appropriate institutional and legal framework. For instance, the 2017 revision of the EU Cybersecurity Strategy highlights the threat posed by hybrid warfare by third countries in the field of information, and it calls for the adoption of appropriate measures (European Parliament, 'EU strategic communication to counteract propaganda against it by third parties,' Resolution (Brussels: 23 November 2016)). It is less clear, however, how these efforts have trickled down to inform crisis responses. 
operations that gave the last shove to Gaddafi's regime in 2011, Russia saw the use of the $\mathrm{R}_{2} \mathrm{P}$ doctrine to justify the attack on Libya as a fig-leaf to cover a dangerous military escalation prompted by the West for self-interested geopolitical reasons. ${ }^{70}$ The ensuing diplomatic stalemate paved the way to developing hybrid warfare strategies, the deployment of which far beyond Russian's traditional area of geopolitical influence reflects the non-linearity of Moscow's hybrid contest against the West. Russia has supported eastern-based military and political actors who oppose the GNA, including the Libyan National Army's (LNA's) self-styled leader, warlord Khalifa Haftar. Following face-to-face meetings with high-level officers in Moscow, Russia sent four billion Libyan dinars to the rival 'Eastern' Central Bank of Libya and supplied the LNA with training, advice, and equipment maintenance, as well as alleged weapons deliveries, which circumvented the UN-enforced arms embargo thanks to complacent proxy states such as Egypt and the United Arab Emirates. ${ }^{71}$

Early conjectures that Moscow's behavior in Libya was motivated more by economic than geostrategic appetites proved misleading. In hybrid warfare, after all, the threshold between the two domains is porous and often deceptive. ${ }^{72}$ Consolidating transnational business networks in the context of conflict and post-conflict recovery has contributed to further entrenching a hybrid political order in Libya. There is no shortage of reports that international actors, including Moscow, are leveraging the consolidation of wartime networks among informal actors such as Libyan powerbrokers and foreign private military contractors in order to further their economic and strategic ambitions. ${ }^{73}$

The EU has demonstrated a limited capacity to adapt its Libyan crisis response to these emerging challenges. While it joined the international community in formally endorsing the multilateral peace agreement and GNA, many regional powers began to pursue their own interests by providing substantial under-the-table support to alternative Libyan proxies such as the LNA. Brussels's rigidly state-centric form of crisis response has severely constrained its options, however, by limiting its capacity to adequately address rivalries played out informally at a more subterranean yet equally pernicious level. ${ }^{74}$ This has not only increased the leverage of non-European countries interested in overthrowing the GNA, but has also led to cleavages and dissension among European states themselves. ${ }^{75}$ The ensuing undermining of EU decision-making

70 Rebecca Adler-Nissen, Vincent Pouliot. "Power in Practice: Negotiating the International Intervention in Libya." European Journal of International Relations2O, no. 4 (January 2014): 889-911.

Kars De Bruijne, Floor El Kamouni-Janssen, Fransje Molenaar, "European security interests at stake in Libya?."Clingendael Crisis Alert Report. Den Haag (2017) 111-15. stake in Libya?" Clingendael Crisis Alert Report. Den Haag (2017) 111-15.

73 Information surfacing in meetings with Libyan civil society actors and policy analysts, Tunis, September 2019.

74 Interview with EU officers and policy analysts, Tunis, October 2017; and Brussels, April 2018.

75 Interviews with EU and EU-member states officers, Tunis and Rome, October and November 2017 . 
could be interpreted as a classic hybrid warfare goal. Even more worryingly, one could speculate that European audiences' overriding concern about irregular migration may have been fueled by hybrid warfare informational campaigns. Interestingly, the foreseeable outcome of overemphasis on an alleged migration 'crisis' was the rise of anti-migration parties with alleged ties to Moscow in many European countries. ${ }^{76}$ Similarly, the apparently surprising fact that Russia blocked a May 2018 UN Security Council proposal to impose targeted sanctions on human traffickers in Libya might make sense if we consider that continuing large-scale migration helps keep Europe both occupied and divided.

As emerging evidence appears to corroborate this tentative interpretation, there is little doubt that the EU was unprepared to deal with emerging hybrid warfare in Libya. Indeed, the state-centricity of Brussels's current crisis response toolbox renders geostrategic competition by informal means both invisible and intractable.

The rise of hybrid warfare in the Ukrainian conflict was more obvious and problematic. The fall of Viktor Yanukovych's government following the February 2014 'Revolution of Dignity' triggered Russian anxieties that a West-leaning, liberal Ukraine might discontinue Russia's naval basing rights in Crimea and even seek early NATO entry. ${ }^{77}$ Less than a week later, unidentified militias took control of strategic political nodes in Crimea, calling for the peninsula to be annexed into the Russian Federation. It was soon apparent, however, that newly-formed rebel and volunteer self-defense groups included Russian military and auxiliaries deployed without insignia (eventually dubbed "little green men"), supported by local strongmen with criminal and political ties to Russia. ${ }^{78}$ This imperceptible transition from formal to informal agency illustrates that the Kremlin increasingly resorts to criminal networks as service providers to pursue geopolitical goals. ${ }^{79}$ The EU's state-centric focus may help explain its ambivalent reaction to the Crimea crisis, condemning Russia but stopping short of defining it as an act of aggression. Lacking an adequate framework to grasp the hybridity of the new warfare deployed in Crimea, the EU has not held Moscow leadership accountable.

However, the most consequential manifestation of hybrid warfare against Ukraine occurred in the so-called Donetsk and Luhansk Peoples Republic (respectively DPR and LPR) in the Donbas region. Available evidence concurs in suggesting that the Kremlin substantially contributed to supporting, if not engineering, protests by local allegedly Russophone communities against the post-Euromaidan regime in Kyiv. These eventually evolved into overt armed insurrections when protesters, storming

76 Rick Noack, “The European parties accused of being influenced by Russia." Washington Post (November 17, 2017) 1-2.

77 Mark Galeotti, "Hybrid, ambiguous, and non-linear? How new is Russia's 'new way of war'?” Small Wars \& Insurgencies 27, no. 2 (2016): 282-301.

78 Mark Galeotti, "Hybrid, ambiguous, and non-linear? How new is Russia's 'new way of war'?" Small Wars \& Insurgencies 27, no. 2 (2016): 282-301.

79 Mark Galeotti, "Hybrid, ambiguous, and non-linear? How new is Russia's 'new way of war'?" Small Wars \& Insurgencies 27, no. 2 (2016): 282-301. 
and seizing police and state security agencies in Donetsk and Luhansk, gained access to state arsenals. Reportedly, the "rebels" and "volunteers" joining DNR and LNR forces included technically "on-leave" military advisors, trainers, intelligence officers, private contractors and soldiers informally recruited, armed and brought into the country by Moscow. ${ }^{80}$ This formidable support severely undermined Ukraine's sovereignty in the region, prompting the DPR and LPR to proclaim independence and seek international recognition. Skillfully manipulating the fuzzy line between formality and informality, Russia continues to deny direct military involvement in the Donbas and refuses to recognize the DPR's and LPR's international legal status. At the same time, though, the Russian government has recognized all civil documents issued in DPR and LPR territory, provides humanitarian, economic and political assistance to the breakaway entities and even expedites Russian citizenship applications from these regions. Moscow's aim in the Donbass might not be facilitating secession or even annexation, therefore, but to perpetuate a frozen conflict. In other words, not to create a new state order but to entrench a hybrid political order along a porous borderland.

This logic is essentially alien to European strategic thinking, however, and existing crisis response tools may not be appropriate for addressing it, as demonstrated by the relative ineffectiveness of EU sanctions that only strengthen the grip of criminal organizations with vested interests in perpetuating this ambivalent conflict. At the same time, European intelligence agencies endorsing the securitization of vaguely defined hybrid warfare neglect the significance of hybrid political orders and thus fail to recognize clientelist connections between non-state actors (criminals, community leaders, etc.) and their political counterparts.

\section{Concluding Observations}

While most available peace scholarship tends to distinguish between the past liberalism and current "pragmatism", if not realism, of EU crisis response, we suggest nuancing this rigid demarcation. Stabilization-focused EU crisis response borrows some narratives, policies, and legitimacy from liberal peacebuilding, but it also prioritizes and expands the specific set of liberal peacebuilding provisions concerned with restoring, strengthening, and stabilizing the target state's sovereign prerogatives while placing a lesser emphasis on the promotion of liberal values. This prioritization reflects a major shift, recasting the state from potential threat to key referent object in need of securing.

Clearly departing from liberal orthodoxy, ${ }^{81}$ this reframing has led to what we have called a state-centric approach to crisis response. This is best understood as a normative-epistemological commitment to focusing on and engaging with formal state structures imagined according to the Weberian ideal-type. The evidence discussed

8o Mark Galeotti, "Hybrid, ambiguous, and non-linear? How new is Russia's 'new way of war'?” Small Wars \& Insurgencies 27, no. 2 (2016): 282-301.

81 David Roberts, Liberal peacebuilding and global governance: beyond the metropolis. (London: Routledge, 2011), 205-06. 
herein, however, suggests that EU crisis response lacks contextual adaptation and conflict sensitivity: by projecting abstract Weberian rationality on target countries, it overlooks the crucial significance of alternative logics of order unfolding just outside (and possibly within) EU borders. Indeed, while the post-Lisbon framework stressed a variety of threats and referent objects to be secured, the EU's state-centricity underpinning its stabilization policies occlude important insights to be derived from more multi-layered perspectives sensitive to the plural agencies and informal rules involved in conflict formation, transformation, and resolution, placing it increasingly at odds with the expanding literature on non-state security providers. ${ }^{82}$

This fine-grained empirical analysis of EU crisis response in key neighbors such as Libya and Ukraine suggests that the EU approach to SSR, humanitarian assistance, and warfare is strikingly neglectful of the hybrid ordering, peace building and conflict-making dynamics at play in these countries. Soberly eschewing the thorny question of whether these dynamics stem from pre-crisis state-building processes, the entrenchment of wartime legacies, or short-sighted post-war stabilization measures, we simply argue that EU crisis response may be in need of improvement because its over-emphasis on state-centric stabilization fails to adequately address the enduring gap between ambitions and results.

Hence, just as much as the hybrid peace scholarship may be seen as a way of addressing these contradictions by either redressing or expanding liberal peacebuilding, our analysis could be interpreted as an initial attempt to emphasize the benefits of a "hybrid turn" in stabilization as well. ${ }^{83}$ This should be tasked with investigating the "local everyday practices" of "what truly constitutes order" as a baseline for sustainable crisis response. ${ }^{84}$ Although more research is required to further corroborate our findings, we argue that factoring hybridity in might provide valuable insights to help bring EU crisis response in line with its ambition of "principled pragmatism."

\section{Bibliography}

Adler-Nissen, Rebecca and Pouliot Vincent. "Power in practice: Negotiating the international intervention in Libya." European Journal of International Relations 20, no. 4 (January 2014): 889-911.

Albrecht, Peter and Wiuff Moe Lousie. "The Simultaneity of Authority in Hybrid Orders." Peacebuilding 3, no. 1 (2015): 1-16.

Bach, Daniel C. and Mamoudou Gazibo (eds.). Neopatrimonalism in Africa and Beyond. New York: Routledge, 2012.

82 Donais, Timothy. "Engaging Non-State Security Providers: Whither the Rule of Law?" International Journal of Security \& Development 6, no. 1 (2017).

83 Roger MacGinty, International Peacebuilding and Local Resistance: Hybrid Forms of Peace. Basingstoke: Palgrave Macmillan, 2011, 203-06.

84 Volker Boege, "Potential and limits of traditional approaches in peacebuilding." in Advancing Conflict Transformation. The Berghof Handbook II. eds. Beatrix Austin, Martina Fischer, and Hans J. Giessmann. (Opladen: Barbara Budrich Publishers, 2011): 433. 
Bagayoko, Niagale and Eboe Hutchful, and Robin Luckham. "Hybrid Security Governance in Africa: Rethinking the Foundations of Security, Justice and Legitimate Public Authority." Conflict, Security \& Development 16, no. 1 (2016): 1-32.

Belloni, Roberto. "Hybrid Peace Governance: Its Emergence and Significance." Global Governance 18, no. 1 (2012): 21-38.

Boege, Volker. "Potential and Limits of Traditional Approaches in Peacebuilding." in Advancing Conflict Transformation. The Berghof Handbook II. eds. Beatrix Austin, Martina Fischer, and Hans J. Giessmann. (Opladen: Barbara Budrich Publishers, 2011): 433 .

Bojicic-Dzelilovic, Vesna and Denisa Kostovicova, and Elisa Randazzo. "EU in the Western Balkans: Hybrid Development, Hybrid Security and Hybrid Justice." Security in Transitions Working Paper no. o3/16 (2016).

Charlemagne. "Europe's Ring of Fire." The Economist, (September 20, 2014).

Clapham, Christopher. "The global-local politics of state decay," in When states fail: causes and consequences. ed. Robert I. Rotberg. (Princeton, NJ: Princeton University Press, 2003).

Cole, Peter, and Fiona Mangan. "Policing Libya. Form and Function of Policing since the 2011 Revolution." Peacework, no. 117, (Washington: USIP. 2016).

De Bruijne, Kars, El Kamouni-Janssen, Floor, and Molenaar, Fransje. "European security interests at stake in Libya?"Clingendael Crisis Alert Report. Den Haag (2017).

Debiel, Tobias and Rinck Patricia. "Statebuilding," in: Routledge Handbook of Security Studies, 2nd edition. eds. M. Dunn Cavelty and T. Balzacq. (London: Routledge, 2017).

Donais, Timothy. "Engaging Non-State Security Providers: Whither the Rule of Law?" International Journal of Security \& Development 6, no. 1 (2017).

Eaton, Tim. "Libya's War Economy: Predation, Profiteering, and State Weakness." Chatham House Research Paper 4 (2018).

EEAS. "EUBAM Libya Initial Mapping. Report Executive Summary." (Brussels, Belgium: Council of the European Union, January2017).

European Commission. "Decision on the establishment of a European Union Emergency Trust Fund for stability and addressing root causes of irregular migration and displaced persons in Africa." (Brussels, Belgium: October 20, 2015).

European Commission. "Shared Vision, Common Action: A Stronger Europe. A Global Strategy for the European Union's Foreign and Security Policy." (Brussels, Belgium: June 2016).

European Commission. "Migration on the Central Mediterranean route. Managingflows, saving lives." (Brussels, Belgium: January 25, 2017).

European Commission, High Representative of the Union for Foreign Affairs and Security Policy. "Review of the European Neighbourhood Policy." (Brussels, Belgium: November 18, 2015).

Galeotti, Mark. "Hybrid, Ambiguous, and Non-linear? How New is Russia's 'New Way of War'?" Small Wars \& Insurgencies 27, no. 2 (2016): 282-301.

Galeotti, Mark. "Crimintern: How the Kremlin Uses Russia's Criminal Networks in Europe." ECFR Policy Brief (2017). 
Goldgeier, James and Michael McFaul. "The Liberal Core and the Realist Periphery in Europe." Perspectives on European Politics and Society 2, no. 1 (2001): 1-26.

Ivashchenko-Stadnik, Kateryna. "What's wrong with the Donbas? The challenges of integration before, during, and after the war," in Ukraine in Transformation: from Soviet Republic to European Society. eds. A. Veira Ramos and T. Lubiva. (London: Palgrave, 2020): 229-6o.

Ivashchenko-Stadnik, Kateryna, and Roman Petrov, Luca Raineri, Pernille Rieker, Alessandra Russo, and Francesco Strazzari. "How the EU is facing crises in its neighbourhood: evidence from Libya and Ukraine.” EUNPACK Working Paper D6.1. (2017).

Ivashchenko-Stadnik, Kateryna, and Roman Petrov, Pernille Riekerand, Alessandra Russo. "The Implementation of the EU's crisis response in Ukraine." EUNPACK Working Paper D6.3. (2018).

Ivashchenko-Stadnik, Kateryna, and Roman Petrov, Alessandra Russo. "A Summary of Perception Studies in Ukraine.” EUNPACK Policy Brief D6.4. (2017).

Jayasundara-Smits, Shyamika. "From Revolution to Reform and Back: EU-Security Sector Reform in Ukraine." WOSCAP article D4.14. (2016).

Kaldor, Mary. Global Security Cultures. Cambridge, UK: Polity Press, 2018.

Krause, Keith. "Hybrid Violence: Locating the Use of Force in Postconflict Settings." Global Governance: A Review of Multilateralism and International Organizations 18, no. 1 (August 12, 2012): 39-56.

Lacher, Wolfram. "Tripoli's militia cartel." SWP Comment 20/2018. (Berlin: Stiftung Wissenschaft und Politik, 2018).

Lawrence, Michael. "Security Provision and Political Formation in Hybrid Orders. Stability." International Journal of Security and Development 6, no. 1 (2017): 10.

Likhachev, Vyacheslav. "Far-right Extremism as a Threat to Ukrainian Democracy." Nations in Transit Brief. (Washington, DC: Freedom House, Freedom House Nations in Transit Brief, 2018).

Leonid Litra, Ivan Medynskyi, and Kateryna Zarembo. "Assessing the EU's conflict prevention and peacebuilding interventions in Ukraine." WOSCAP Case Study Report D3.4.(2016).

Loschi, Chiara, and Luca Raineri. "Perceptions about the EU's Crisis Response in Libya." EUNPACK Policy Brief D6.4. (2017).

Loschi, Chiara, and Luca Raineri, Francesco Strazzari. "The implementation of EU Crisis Response in Libya: Bridging theory and practice." EUNPACK Working Paper D6.2. (2018).

MacGinty, Roger. International Peacebuilding and Local Resistance: Hybrid Forms of Peace. Basingstoke: Palgrave Macmillan, 2011.

Manners, Ian. “Normative Power Europe: A Contradiction in Terms?" Journal of Common Market Studies 40, no. 2 (2002): 235-58.

Messner J. J. and Blyth Hannah. "Springtime for Castro and Cuba; Winter for Ukraine and Libya in Fragile States Index, The Fund for Peace." (2015): 13. Accessed 
December 13, 2020. https://reliefweb.int/sites/reliefweb.int/files/resources/ fragilestatesindex-2015.pdf.

Messner J.J. (ed.). Fragile States Index, The Fund for Peace (2020): 6. Accessed December 13, 2020. https://fragilestatesindex.org/wp-content/uploads/2020/05/ fsi2020-report.pdf.

Nadarajah, Suthaharan and Rampton David. "The Limits of Hybridity and the Crisis of Liberal Peace." Review of International Studies 41, no. 1 (2015): 49-72.

Noack, Rick. "The European parties accused of being influenced by Russia." Washington Post (November 17, 2017).

Polese, Abel. "Limits of a Post-Soviet State: How Informality Replaces, Renegotiates, and Reshapes Governance in Contemporary Ukraine.” Stuttgart: Ibidem Verlag (2016).

Polese, Abel, Kevilhan Rob, and Ó-Beacháin Donnacha. "Introduction: hybrid warfare in post-Soviet spaces, is there a logic behind?" Small Wars \& Insurgencies 27, no. 3 (2016).

Pomorska, Karolin, and Gergana Noutcheva. "Europe as a Regional Actor: Waning Influence in an Unstable and Authoritarian Neighbourhood." Journal of Common Market Studies 55, no. 1 (2017): 165-76.

Prodi, Romano. "A Wider Europe: A Proximity Policy as the Key to Stability," in 6th ECSA World Conference Peace, Security and Stability International Dialogue and the Role of the EU. (Brussels: on 5-6 December 2002).

Pusztai, Wolfgang. "The Haftar-Russia link and the Military Plan of the LNA." ISPI Dossier 2 (2017).

Richmond, Oliver and Mitchell Audra. Hybrid Forms of Peace: From Everyday Agency to Post-Liberalism. Basingstoke: Palgrave Macmillan (2012).

Richmond, Oliver. "Failed Statebuilding versus Peace Formation." Cooperation and Conflict 48, no. 3 (2013).

Richmond, Oliver, and Sandra Pogodda, and Roger MacGinty. "Good intentions, mixed results - A conflict sensitive unpacking of the EU comprehensive approach to conflict and crisis mechanisms." EUNPACK Working Paper D.3.2.(2016).

Rieker, Pernille. External governance as security community building: the limits and potential of the European Neighbourhood Policy. (London, UK: Palgrave Macmillan, 2016).

Roberts, David. Liberal peacebuilding and global governance: beyond the metropolis. (London: Routledge, 2011).

Schnaufer, Tad. "Redefining Hybrid Warfare: Russia's Non-linear War against the West." Journal of Strategic Security 10, no. 1 (2017).

Shaw, Mark and Mangan, F. "Enforcing 'Our Law' When the State Breaks Down: The Case of Protection Economies in Libya and Their Political Consequences." Hague Journal on the Rule of Law 7, no. 1 (2015): 99-110.

Stocker, Valerie. "Leaving Libya: Rapid Assessment of Municipalities of Departures of Migrants in Libya." Tunis: Altai Consulting 92 (2017). 
Taft, Patricia. "Libya Continues Path as the Decade's Most Worsened Country." Fragile States Index, The Fund for Peace (2020): 27, 28. Accessed December 13, 2020. https://fragilestatesindex.org/2020/05/10/libya-continues-path-as-the-decadesmost-worsened-country/.

Tardy, Thierry. "Tackling the challenges of SSR." EUISS Issue Alert 14 (2015).

United Nations. Interim report of the Panel of Experts on Libya established pursuant to resolution 1973 (2011). New York: USA, 2017.

United Nations. Report to the Security Council (unpublished) (2018).

Dr. Luca Raineri is a researcher in Security Studies at the Sant'Anna School of Advanced Studies in Pisa, Italy. His research focuses mainly on transnational security threats across Africa and the Mediterranean. Dr. Raineri holds a degree in Political Theory from the Ecole des Hautes Etudes en Sciences Sociales (EHESS) in Paris, and a PhD in Global Politics from the Sant'Anna School of Advanced Studies (2016). His work has been published in academic journals such as African Security, Civil Wars, and the Journal of Peacebuilding and Development.

Dr. Kateryna Ivashchenko-Stadnik: PhD (2000), Senior Research Fellow of the Department of Methodology and Methods of Social Research, Institute of Sociology, National Academy of Sciences; Member of the Advisory Board of the National Institute of Strategic Studies (Kyiv, Ukraine). Since 2020 she is also a Kyiv-based consultant at the Centre for Sustainable Peace and Democratic Development (SeeD). Academic interests: forced displacement, societal change during conflicts, international development.

Prof. Dr. Roman Petrov is Head of the Jean Monnet Centre of Excellence in EU Studies at the National University of Kyiv-Mohyla Academy. He is active in publishing in internationally recognised peer-review journals. He is the founder and first elected president of the Ukrainian European Studies Association. Areas of Prof. Dr. Petrov's research and teaching include: EU Law, EU Business Law; EU External Relations Law; Approximation and Harmonisation of Legislation in the EU; Legal Aspects of Regional Integration in the Post-Soviet Area.

Acknowledgements: This work was carried out thanks to the financial support for the research by the EU Commission Horizon 2020 Project EUNPACK—Good intentions, mixed results. A conflict sensitive unpacking of the EU comprehensive approach to conflict and crisis mechanisms [H2O2O-INT-05-2015], Grant Agreement n. 693337 http://www.eunpack.eu. 


\title{
Відповідаючи на Гібридність у Нестабільному Сусідстві: Ефективність Державоцентричного Підходу ЄС до Криз у Лівії та Україні
}

\author{
Лука Райнері \\ Дослідник \\ Школа прикладних наук Св. Анни, Італія \\ Катерина Іващенко-Стаднік \\ Старший дослідник \\ Національна академія наук, Україна
}

\section{Роман Петров}

Керівник кафедри ім. Жана Моне з права ЄС

Національний університет “Києво-Могилянська академія”, Україна

\begin{abstract}
Анотація
Ця стаття присвячена дослідженню комплексних проблем, які походять з різноманіття традиційних ліберальних підходів до нового типу комплексних надзвичайних ситуацій. Ґрунтуючись на глибинному емпіричному аналізі, вона досліджує роль ЄС у впливі на реформи безпекового сектору, гуманітарну допомогу, у контексті бойових дій в Лівії та Україні як двох ключових держав-сусідів EC, у яких тривають військові протистояння. Стаття визначила, що досліджуваний надмірний акцент на державоцентричні стабілізаційні заходи, які спрямовані передусім на участь державних структур, не дає змоги адекватно реагувати на гібридну динаміку конфліктів та заходів зі встановлення миру в обох країнах. Пропонується застосовувати багатоаспектний підхід до безпекових питань, який мав би розроблятися як в межах кордонів $\mathcal{E}$, так і поза ними.
\end{abstract}

Ключові слова: Європейський Союз, відповіді на кризу, гібридність, реформи безпекового сектору, гуманітарна допомога, стабілізація 